\title{
ANALISIS LITERASI KEUANGAN, INKLUSI KEUANGAN DAN PENDAPATAN TERHADAP PERILAKU PELAKU UMKM DI DEPOK JAWA BARAT
}

\section{Dahlia Pinem dan Bernadin Dwi M}

Universitas Pembangunan Nasional (UPN) Veteran Jakarta, Jawa Barat, Indonesia

Email: pinem_dahlia@yahoo.com dan bernadindwim@yahoo.com

\begin{abstract}
This study aims to analyze the influence of Financial Literacy, Financial Inclusion and Income on Financial Behavior in Micro, Small and Medium Enterprises in Depok, West Java. This research is a quantitative research. Data collection is used through distributing questionnaires. Measurement of the variables using a Likert scale. The analysis technique used is the PLS (Partial Least Square) analysis method. The variables used in this research are Financial Literacy, Financial Inclusion, Income are independent variables while the dependent variable is financial behavior. The population in this study were all micro, small and medium enterprises in Depok City. The sample size used was 100 respondents with probability sampling methods, especially simple random sampling. The results of this study indicate that financial literacy, financial inclusion and income have a significant influence on financial behavior. Financial Literacy Knowledge for MSME Players needs attention in managing a business so that they can make correct and effective decisions, which in turn can improve the performance of MSMEs.
\end{abstract}

Keywords: financial literacy; financial inclusion and income and financial behavior

\begin{abstract}
Abstrak
Penelitian ini bertujuan untuk menganalisis pengaruh Literasi Keuangan, Inklusi Keuangan dan Pendapatan terhadap Perilaku Keuangan pada Pelaku Usaha Mikro, Kecil dan Menengah di Kota Depok Jawa Barat. Metode penelitian ini merupakan penelitian yang bersifat kuantitatif. Pengumpulan data digunakan melalui penyebaran kuesioner. Pengukuran Variabelnya dengan menggunakan skala Likert. Teknik analisis yang digunakan adalah metode analisis PLS (Partial Least Square). Variabel yang digunakan dalam penelitian ini adalah Literasi Keuangan, Inklusi Keuangan, Pendapatan merupakan Variabel Independen sedangkan Variabel Dependennya adalah Perilaku Keuangan. Populasi dalam penelitian ini adalah seluruh usaha mikro, kecil dan menengah di Kota Depok. Ukuran sampel yang digunakan sebanyak 100 responden dengan metode probability sampling khususnya simple random sampling. Hasil penelitian ini menunjukkan literasi keuangan, Inklusi Keuangan dan pendapatan memiliki pengaruh signifikan terhadap perilaku keuangan. Pengetahuan Literasi Keuangan bagi Pelaku UMKM perlu mendapat perhatian dalam mengelola Usaha sehingga dapat mengambil keputusan yang benar dan efektif, yang akhirnya dapat meningkatkan Kinerja UMKM.
\end{abstract}


Kata kunci: literasi keuangan; inklusi keuangan dan pendapatan dan perilaku keuangan

Coresponden Author

Email:pinem_dahlia@yahoo.com Artikel dengan akses terbuka dibawah lisensi

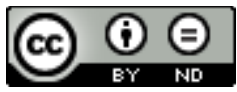

\section{Pendahuluan}

UKM di Indonesia merupakan bagian yang sangat penting dalam suatu perekonomian dikarenakan dapat menyerap tenaga kerja yang tinggi dan dapat bertahan pada saat krisis Ekonomi tahun 1998. Jumlah UMKM pada tahun 2018 diprediksi sebanyak 58,95 juta dan Jumlah penduduk Indonesia diperkirakan 265 juta jiwa. Menurut penjelasan Deputi Bidang Pembiayaan Kementerian Koperasi dan UKM, Kemkop UKM Yuana juga membeberkan data Badan Pusat Statistik, tercatat 3,79 juta pelaku UMKM telah memanfaatkan teknologi digital atau bisnis e-commerce. Kebanyakan pelaku UMKM memanfaatkan platform market place utama di Tanah Air, seperti Blibli, Tokopedia, Lazada dan Bukalapak. Di Indonesia Pemerintah memperkirakan kontribusi sektor usaha mikro, kecil, dan menengah (UMKM) terhadap produk domestik bruto (PDB) pada tahun ini bisa tumbuh hingga melebihi capaian tahun lalu sebesar $62 \%$ karena jumlah pelaku UMKM terus bertambah. UMKM memberikan kontribusi yang cukup signifikan terhadap perekonomian negara di seluruh dunia, sehingga sangat perlu diperhatikan. Secara statistik, UMKM memberikan kontribusi 57,9\% terhadap PDB Indonesia dan menyerap 97\% dari pekerja nasional sehingga OJK memandang UMKM perlu diberdayakan dan ditingkatkan untuk mendorong perekonomian negara dan peningkatan kesejahteraan rakyat.

Namun pada kenyataannya masih ada UMKM yang belum mampu mengelola usahanya dengan baik, karena kurangnya pengetahuan tentang Literasi Keuangan, sehingga tidak jarang pula UMKM yang gagal dalam usahanya. Pengelolaan usaha yang perlu diperhatikan adalah pengelolaan dalam bidang pengetahuan tentang keuangan. Pengelolaan keuangan menjadi suatu masalah dalam UMKM karena pemilik UMKM mengabaikan pentingnya pengelolaan keuangan. Menurut (Suryanto, 2017), Perilaku keuangan menerangkan bagaimana seseorang memperlakukan, mengelola, dan menggunakan sumber keuangan yang dimilikinya. Keuangan individu dapat dikelola dengan baik apabila perilaku keuangannya tersebut dikelola dengan bertanggungjawab. Perilaku keuangan merupakan salah satu isu yang banyak dibahas belakangan ini. Hal tersebut berdampak dari banyaknya fenomena yang timbul pada masyarakat Indonesia perihal pengelolaan keuangan yang kurang baik. Maka untuk meminimalisir perilaku keuangan yang kurang baik, setiap individu harus memiliki pemahaman mengenai keuangan yang baik sehingga dapat terhindar dari masalah keuangan yang mungkin dapat terjadi.

Menurut (Keuangan, 2015), pemahaman mengenai keuangan dapat juga disebut sebagai literasi keuangan. Yang merupakan tingkat pengetahuan, keterampilan, 
keyakinan yang mempengaruhi sikap dan perilaku untuk meningkatkan kualitas pengambilan keputusan dan pengelolaan keuangan dalam rangka mencapai kesejahteraan

Perilaku keuangan adalah salah satu konsep penting dalam disiplin ilmu keuangan. (Bodie, Kane, \& Marcus, 2014), Perilaku keuangan adalah teori tentang keuangan biasa yang mengabaikan bagaimana perilaku orang-orang di dunia nyata dalam mengambil suatu keputusan dan membuat suatu perbedaan. Menurut (Al Kholilah \& Iramani, 2013), Perilaku keuangan adalah kemampuan yang dimiliki oleh seseorang dalam mengatur yaitu perencanaan, penganggaran, pemeriksaan, pengelolaan, pengendalian, pencarian dan penyimpanan dana keuangan sehari-hari. Perilaku keuangan masyarakat Indonesia yang cenderung konsumtif kemudian menimbulkan berbagai perilaku keuangan yang tidak bertanggungjawab lainnya seperti kurangnya kegiatan menabung, investasi, perencanaan dana darurat dan penganggaran dana untuk masa depan. Banyak pelaku UMKM yang tidak melakukan perencanaan, penganggaran, pemeriksaan, pengelolaan, pengendalian, pencarian dan penyimpanan keuangan, salah satunya adalah pembuatan laporan keuangan, jadi para pelaku UMKM hanya membuat laporan keuangan sederhana yang berisi pendapatan dan pengeluaran itu pun tidak detail dan tidak sesuai dengan laporan keuangan yang seharusnya. Hal tersebut sejalan dengan penelitian (Wirjono \& Raharjono, 2012) Kebanyakan pelaku UMKM tidak pernah membuat pembukuan ataupun terkait dengan manajemen usahanya. Hal tersebut dikarenakan pengetahuan para pelaku UMKM yang rendah dalam pengelolaan keuangan.

Inklusi Keuangan merupakan upaya untuk meniadakan segala bentuk hambatan harga maupun non harga terhadap akses masyarakat dalam memanfaatkan layanan jasa keuangan (Hidayat, Fuad, \& Nurhidayati, 2018). Sedangkan menurut (Keuangan, 2015) Inklusi Keuangan merupakan ketersediaan akses pada berbagai lembaga, produk dan layanan jasa keuangan sesuai kebutuhan dan kemampuan masyarakat dalam rangka meningkatkan kesejahtraan. Berdasarkn Penelitian (Bongomin, Ntayi, Munene, \& Malinga, 2017) ada 4 (empat) pengukuran inklusi keuangan yaitu: access, usage, welfare, quality. Kemudian (Keuangan, 2015) membagi indikator dalam inklusi keuangan yaitu akses, ketersediaan produk dan layanan jasa keuangan, penggunaan produk dan layanan jasa keuangan, dan kualitas

Pendapatan yang diterima seseorang, seharusnya berbanding lurus dengan perilaku keuangan orang tersebut. Seseorang yang memiliki pendapatan yang lebih tinggi kemungkinan besar berperilaku keuangan yang baik, karena dana yang tersedia memberikan mereka kesempatan untuk bertindak lebih bertanggung jawab (Purwidianti \& Mudjiyanti, 2016). Berdasarkan penelitian yang dilakukan oleh Andrew dan Linawati (2014) menyatakan bahwa pendapatan berpengaruh terhadap perilaku keuangan. Sedangkan penelitian yang dilakukan oleh (Purwidianti \& Mudjiyanti, 2016) menyatakan bahwa tingkat pendapatan tidak berpengaruh terhadap perilaku keuangan. Pada Penelitian Purwidianti hanya menganalisis Pengalaman dan Tingkat Pendapatan Keluarga di Purwodadi Timur, sedangkan Peneliti akan menambahkan Literasi Keuangan dan Inklusi Keuangan di UMKM Depok. 
Penelitian ini memberikan makna bahwa jika literasi keuangan, inklusi keuangan sudah dapat dijalankan Oleh UMKM akan dapat memberikan manfaat yang baik, sehingga kemakmuran atau kesejahteraan masyarakat bisa lebih ditingkatkan. Literasi Keuangan di Kota Depok akan memberikan gambaran Pengetahuan Pengelolaan Keuangan, Perencanaan Keuangan, Pengetahuan Kredit dan Pengetahuan Investasi yang dapat memberikan gambaran tentang Perilaku Pelaku UMKM. Penelitian ini dilakukan untuk mengindari kesalahan dalam mengelola keuangannya. Jika pengelolaan keuangan sudah tepat diharapkan dapat memberikan kontribusi pada UMKM untuk meningkatkan profitabilitas usaha, sehingga UMKM dapat memberikan kesejahtraan bagi pemiliknya dan Kontribusi yang besar terhadap Perekonomian Nasional, khususnya dapat meningkatkan PDRB di Kota Depok.

\section{Metode Penelitian}

Teknik analisis data yang digunakan adalah desktiftif dan analisis PLS. Analisa data yang digunakan dalam penelitian ini adalah Analisa deskriftif. (Ferdinan, 2014). Analisis statistik deskriptif digunakan untuk memberikan gambaran atau deskripsi empiris atas data yang dikumpulkan dalam penelitian. Analisa ini dilakukan untuk mendapatkan gambaran deskriptif responden mengenai variabel-variabel yang digunakan dalam penelitian ini. Persepsi responden tersebut digambarkan menggunakan teknik skoring.

Adapun Teknik skoring yang dilakukan pada penelitian ini adalah terdiri dari peringkat jawaban 1 sampai 5, seperti pada tabel berikut:

Tabel 1

Peringkat Jawaban Kuesioner

\begin{tabular}{ccccc}
\hline Skala Likert & X1 & X2 & X3 & Y \\
\hline 1 & STS & STS & STS & STS \\
\hline 2 & TS & TS & TS & TS \\
\hline 3 & CS & CS & CS & CS \\
\hline 4 & S & S & S & S \\
\hline 5 & SS & SS & SS & SS \\
\hline \multicolumn{5}{r}{ Sumber : Data yang diolah }
\end{tabular}

Sehingga diperoleh tabel interpretasi nilai indeks responden sebagai berikut :

Tabel 2

Interpretasi Nilai Presentase Responden

\begin{tabular}{cc}
\hline Nilai Indeks & Interpretasi \\
\hline $15-34$ & Rendah \\
\hline $35-54$ & Sedang \\
\hline $55-75$ & Tinggi \\
\hline \multicolumn{2}{c}{ Sumber : Ferdinand $(2011)$}
\end{tabular}

(Sugiyono, 2016) Populasi adalah wilayah generalisasi yang terdiri atas objek atau subyek yang mempunyai kualitas dan karakteristik tertentu . 
Populasi yang digunakan dalam penelitian ini adalah seluruh Pelaku Usaha Mikro, Kecil dan Menengah di UMKM di Depok Jawa Barat.

\section{Hasil dan Pembahasan}

\section{A. Karakteristik Responden}

Responden merupakan Pemilik UMKM di Kota Depok yang dimintai keterangan untuk mengisi data kuesioner. Profil Responden yang didapatkan sebanyak 100 UMKM yang terdiri dari kategori Jenis Kelamin (Pria/Wanita), Riwayat Pendidikan (SD, SMP, SMA, D3, S1), Usia (Tahun), Jenis Usaha, Jumlah Karyawan (orang) dan Pendapatan (Jutaan).

Tabel 3

\section{Karakteristik Responden}

\begin{tabular}{|c|c|c|c|}
\hline No & Kategori & Frekuensi & $\%$ \\
\hline \multirow[t]{3}{*}{1.} & Jenis Kelamin & & \\
\hline & Pria & 65 & 65 \\
\hline & Wanita & 35 & 35 \\
\hline \multirow[t]{5}{*}{2.} & Tingkat Pendidikan & & \\
\hline & $\mathrm{SD}$ & 5 & 5 \\
\hline & SMP & 20 & 20 \\
\hline & SMA & 71 & 71 \\
\hline & $\mathrm{D} 3 / \mathrm{S} 1 / \mathrm{S} 2$ & 4 & 4 \\
\hline \multirow[t]{5}{*}{3.} & Usia & & \\
\hline & $17-20$ Tahun & 3 & 3 \\
\hline & $20-29$ Tahun & 15 & 15 \\
\hline & 30 - 39 Tahun & 39 & 39 \\
\hline & $>40 \quad$ Tahun & 43 & 43 \\
\hline \multirow[t]{5}{*}{4.} & Bidang Usaha & & \\
\hline & Perdagangan & 71 & 71 \\
\hline & Produksi & 5 & 5 \\
\hline & Jasa & 14 & 14 \\
\hline & Kuliner & 10 & 10 \\
\hline \multirow[t]{4}{*}{5.} & Jumlah Karyawan & & \\
\hline & $\leq 5$ & 89 & 89 \\
\hline & 5- 9 & 10 & 10 \\
\hline & $10-50$ & 1 & 1 \\
\hline \multirow[t]{5}{*}{6.} & Pendapatan & & \\
\hline & $\leq 5 \mathrm{Juta}$ & 34 & 34 \\
\hline & $5-15$ & 55 & 55 \\
\hline & $16-25$ & 7 & 7 \\
\hline & $>25$ juta & 4 & 4 \\
\hline
\end{tabular}

Sumber: Hasil Pengolahan Data

Dari tabel diatas dapat dilihat karakteristik 100 responden dari sisi jenis kelamin didapatkan jumlah responden di dominasi oleh responden laki-laki dengan jumlah 65 orang dan wanita sejumlah 35 orang. Jika dilihat dari sisi riwayat pendidikan tamat SMA dengan jumlah 71 orang dan pendidikan tamat SMP 
sejumlah 20 orang D3/S1/S2 sebanyak 4 orang, Jika dilihat dari usia responden, ratarata usia didominasi oleh usia 30- 39 tahun dengan jumlah responden sejumlah 39 orang dan usia $>40$ tahun sejumlah 40 orang. Kemudian dari sisi jenis usaha yang dijalankan oleh pemilik UMKM didominasi oleh jenis usaha perdagangan 71 dan kuliner 10, usaha produksi 5 (lima) sementara untuk omzet atau pendapatan perbulan yang dihasilkan oleh UMKM didominasi dengan omzet berkisar 5-15 jutaper bulan sebanyak 55 UMKM; dan pendapatan < 5 juta rupiah per bulan sebanyak 34 UMKM.

\section{B. Model Pengukuran (Outer Model)}

Tahapan awal yang digunakan yaitu melakukan uji loading factor pada setiap indikator yang terdapat didalam masing-masing yang sudah memunuhi convergent validity. Maka hasil diagram jalur sebagai berikut:

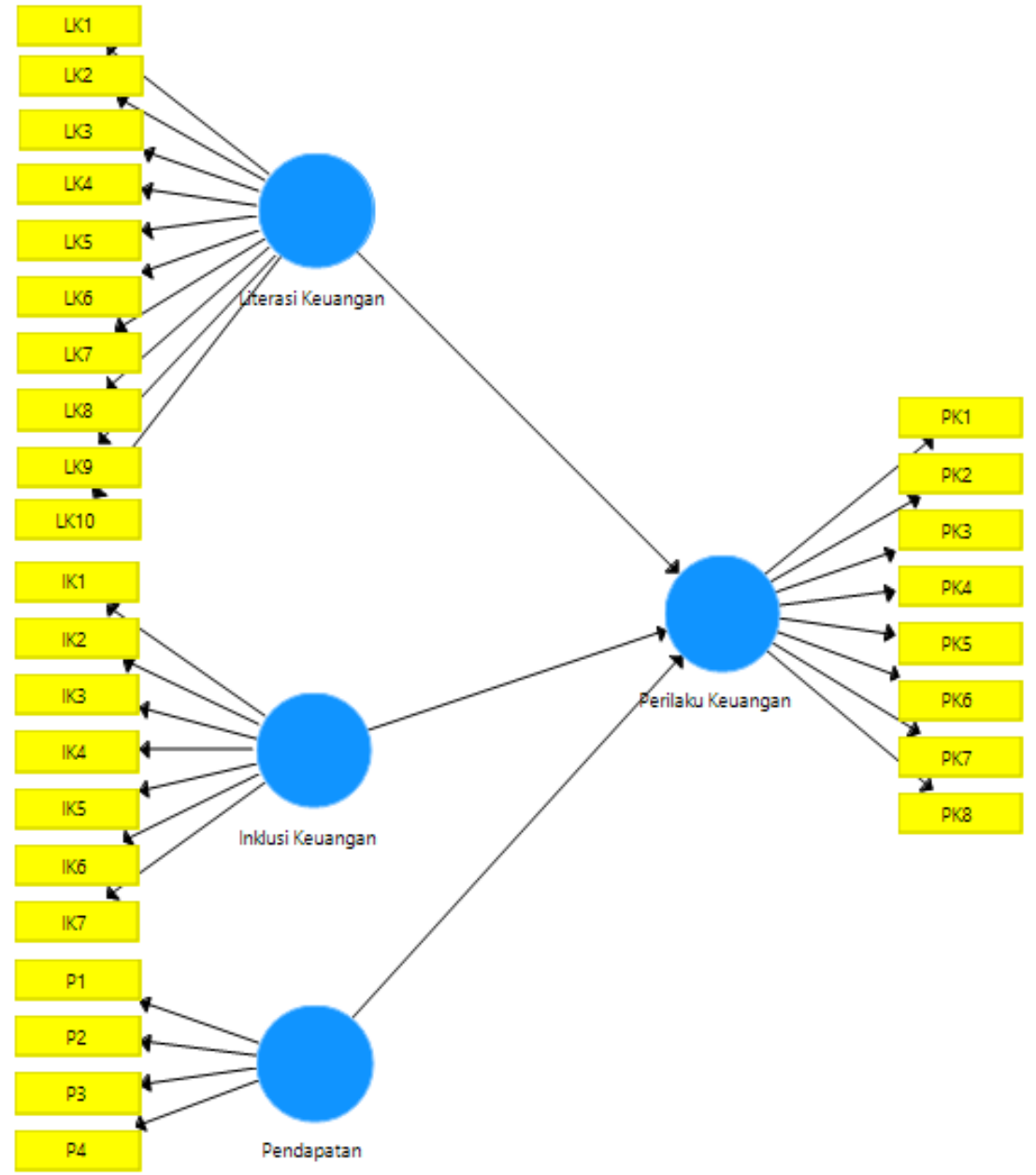

Sumber : Hasil Output Smart PLS 3.0

\section{Gambar 2}

Nilai Loading Factor Outer Model 
Pada gambar diatas indikator yang memiliki nilai korelasi 0,50 sampai dengan 0,60 masih dapat diterima atau dianggap valid (Ghozali, 2016). Instrumen pernyataan pada literasi keuangan, inklusi keuangan, pendapatan dan perilakun keuangan menunjukan semua indikator pada setiap variabel dapat dikatakan valid dan dapat digunakan dalam penelitian ini karena telah memenuhi convergent validity atau nilai korelasinya berada di atas 0,5. Hal ini menunjukan bahwa model pengkuran dalam variabel tersebut telah berhasil memenuhi syarat, sehingga dapat melakukan pengujian data selanjutnya.

\section{Uji Validitas Konvergen}

Dibawah ini merupakan hasil output software Smart PLS 3.0:

\section{Tabel 4}

Outer Factor Model

\begin{tabular}{|c|c|c|c|c|}
\hline & $\begin{array}{l}\text { Perilaku } \\
\text { Keuangan (Y) }\end{array}$ & $\begin{array}{c}\text { Literasi Keuangan } \\
\left(\mathrm{X}_{1}\right)\end{array}$ & $\begin{array}{c}\text { Inklusi Keuangan } \\
\left(\mathrm{X}_{2}\right)\end{array}$ & $\begin{array}{l}\text { Pendapatan } \\
\left(\mathrm{X}_{3}\right)\end{array}$ \\
\hline PK1 & 0,705 & & & \\
\hline PK2 & 0,751 & & & \\
\hline PK3 & 0,833 & & & \\
\hline PK4 & 0,840 & & & \\
\hline PK5 & 0,793 & & & \\
\hline PK6 & 0,785 & & & \\
\hline PK7 & 0,663 & & & \\
\hline PK8 & 0,564 & & & \\
\hline LK1 & & 0,793 & & \\
\hline LK2 & & 0,652 & & \\
\hline LK3 & & 0,770 & & \\
\hline LK4 & & 0,755 & & \\
\hline LK5 & & 0,751 & & \\
\hline LK6 & & 0,656 & & \\
\hline LK7 & & 0,767 & & \\
\hline LK8 & & 0,732 & & \\
\hline LK9 & & 0,684 & & \\
\hline LK10 & & 0,698 & & \\
\hline IK1 & & & 0,805 & \\
\hline IK2 & & & 0,835 & \\
\hline IK3 & & & 0,745 & \\
\hline IK4 & & & 0,717 & \\
\hline IK5 & & & 0,832 & \\
\hline IK6 & & & 0,704 & \\
\hline IK7 & & & 0,564 & \\
\hline $\mathrm{P} 1$ & & & & 0,818 \\
\hline $\mathrm{P} 2$ & & & & 0,831 \\
\hline P3 & & & & 0,550 \\
\hline $\mathrm{P} 4$ & & & & 0,784 \\
\hline
\end{tabular}

Sumber :Outer Loading Factor hasil Ouput SmartPLS 3.0. 


\section{Uji Validitas Diskriminan}

Model yang digunakan untuk melihat discriminant validity adalah dengan melihat nilai squareroot of average variance extracted (AVE). Nilai yang disaran kan adalah diatas 0,5. Berikut merupakan hasil output Smart PLS 3.0. yang diperoleh dari nilai AV

\section{Tabel 5}

Average Variance Extracted (AVE)

\begin{tabular}{|c|c|}
\hline Variabel & Average Variance Extracted (AVE) \\
\hline Inklusi Keuangan (X2) & 0,558 \\
\hline Literasi Keuangan (X1) & $\mathbf{0 , 5 2 9}$ \\
\hline Pendapatan (X3) & 0,569 \\
\hline Perilaku Keuangan (Y) & 0,558 \\
\hline
\end{tabular}

Pada tabel diatas menunjukan semuakonstruk yang ada pada model penelitian dikatakan valid karena memiliki nilai AVE diatas 0,50. Nilai tertinggi AVE adalah variabel pendapatan yaitu sebesar 0,569. Lalu untuk konstruk terendah berada pada variabel literasi keuangan yaitu sebesar 0,529. Dapat disimpulkan bahwa konstruk konstruk literasi keuangan, inklusi keuangan, pendapatan, perilaku keuangan adalah valid dan telah memenuhi syarat pengujian.

Model lain yang digunakan untuk melihat discriminant validity adalah dengan melihat Fornell - Lacker Criterium sebagai berikut:

Tabel 6

Fornell - Lacker Criterium

\begin{tabular}{lcccc}
\hline & $\begin{array}{c}\text { Inklusi } \\
\text { Keuangan }\left(\mathrm{X}_{2}\right)\end{array}$ & $\begin{array}{c}\text { Literasi } \\
\text { Keuangan }\left(\mathrm{X}_{1}\right)\end{array}$ & $\begin{array}{c}\text { Pendapatan } \\
\left(\mathrm{X}_{3}\right)\end{array}$ & $\begin{array}{c}\text { Perilaku Keuangan } \\
(\mathrm{Y})\end{array}$ \\
\hline Inklusi Keuangan $\left(\mathrm{X}_{2}\right)$ & 0,747 & & & \\
\hline Literasi Keuangan $\left(\mathrm{X}_{1}\right)$ & 0,881 & 0,727 & & \\
\hline Pendapatan $\left(\mathrm{X}_{3}\right)$ & 0,741 & 0,858 & 0,754 & 0,747 \\
\hline Perilaku Keuangan $(\mathrm{Y})$ & 0,930 & 0,905 & 0,802 &
\end{tabular}

Sumber : Hasil output smart PLS 3.0

Berdasarkan tebal diatas terlihat bahwa discriminant validity melalui tabel fornell-lacker criterium memiliki nilai diatas 0,6 kepada masing - masing setiap konstruk variabelnya. Inklusi keuangan memiliki nilai konstruk sebesar 0,747, literasi keuangan memiliki nilai 0,727, pendapatan 0,754 dan perilaku keuangan sebesar 0,747. Maka dapat disimpulkan semua konstruk dikatakan valid.

\section{E. Uji Reliabilitas PLS}

Pada smart PLS 3.0 selain menggunakan uji validitas konstruk, juga menggunakan uji reliabilitas konstruk yang diukur dengan composite reliability dan cronbach's alpha. Dibawah ini merupakan hasil output smartPLS 3.0 composite reliability dan cronbach's alpha pada masing-masing konstruk: 
Tabel 7

Composite Reliability

\begin{tabular}{lc}
\hline & $\begin{array}{c}\text { Composite } \\
\text { Realiability }\end{array}$ \\
\hline Inklusi Keuangan $\left(\mathrm{X}_{2}\right)$ & 0,897 \\
\hline Literasi Keuangan $\left(\mathrm{X}_{1}\right)$ & $\mathbf{0 , 9 1 8}$ \\
\hline Pendapatan $\left(\mathrm{X}_{3}\right)$ & $\mathbf{0 , 8 3 8}$ \\
\hline Perilaku Keuangan $(\mathrm{Y})$ & 0,909 \\
\hline \multicolumn{1}{c}{ Sumber: Hasil Output SmartPLS 3.0. }
\end{tabular}

Pada tabel diatas menunjukan bahwa nilai composite reliability untuk semua konstruk adalah $>0,70$. Nilai konstruk composite reliability tertinggi berada pada literasi keuangan dengan nilai 0,918 sedangkan yang terendah berada pada pendapatan dengan nilai 0,838. Namun demikian, seluruh konstruk nilai composite reliability diatas dapat dikatakan memenuhi kriteria karena seluruhnya karena memiliki nilai >0,7. Hal ini menunjukan bahwa semua variabel sangat reliabel terhadap masing-masing konstruknya karena memiliki nilai >0,90 - 1,00.

Tabel 8

Cronbach's Alpha

\begin{tabular}{lc}
\hline & Cronbach's Alpha \\
\hline Inklusi Keuangan $\left(\mathrm{X}_{2}\right)$ & 0,865 \\
\hline Literasi Keuangan $\left(\mathrm{X}_{1}\right)$ & $\mathbf{0 , 9 0 0}$ \\
\hline Pendapatan $\left(\mathrm{X}_{3}\right)$ & $\mathbf{0 , 7 4 6}$ \\
\hline Perilaku Keuangan $(\mathrm{Y})$ & 0,884 \\
\hline \multicolumn{2}{c}{ Sumber: Hasil Ouput SmartPLS 3.0. }
\end{tabular}

Pada uji reliabilitas dapat dilengkapi dengan hasil Cronbach's Alpha. Nilai untuk menjadi reliable pada Cronbach's Alpha adalah harus diatas 0,7. Pada table diatas setiap konstruk memberikan hasil output Cronbach's Alpha diatas 0,7. Nilai Cronbach's Alpha yang terendah berada pada kontruk pendapatan sebesar 0,746. Sedangkan nilai tertinggi berada pada kontruk literasi keuangan sebesar 0,900. Hal ini menunjukan bahwa semua variabel sangat reliabel terhadap tiap-tiap konstruknyaa.

Jadi dapat disimpulkan bahwa uji reliabilitas yang dilakukan dengan composite reliability dan Cronbach's Alpha menghasilkan variabel yang reliabilitas, karena nilai dari setiap variabel melebihi > 0,7 yang artinya jawaban yang diberikan responden terhadap setiap butir pertanyaan adalah konsisten dan stabil sehingga menghasilkan nilai reliabilitas yang baik. 


\section{F. Model Struktural (Inner Model)}

Pengujian terhadap model struktural (innernmodel) ini dilakukan dengan melihat R-Square, Q-Square dan Nilai t-Statistik.

\section{1. $\mathbf{R}$-Square}

Hasil R-Square dari output software smartPLS 3.0 sebagai berikut :

Tabel 9

R-Square

\begin{tabular}{lcc}
\hline & $\begin{array}{c}\text { R- } \\
\text { Square }\end{array}$ & R-Square Adjusted \\
Perilaku Keuangan (Y) & 0,902 & 0,899 \\
\hline & Sumber: Hasil Ouput SmartPLS 3.0.
\end{tabular}

Pada tabel diatas dapat diketahui bahwa besarnya nilai R-Squaree $\left(R^{2}\right)$ perilaku keuangan adalah sebesar 0,902 dan nilai R-Square Adjusted sebesar 0,899. Maka dapat dikatakan nilai R-Square $\left(R^{2}\right)$ pada kontribusi literasi keuangan, inklusi keuangan dan pendapatan terhadap perilaku keuangan adalah sebesar 90,2\% dan sisanya sebesar 9,8\% yang dapat dipengaruhi oleh faktor external dari penelitian ini seperti kepribadian, sikap keuangan, tingkat pendidikan, gaya hidup dan lain sebagainya.

\section{Q -Square}

Uji selanjutnya yang dilakukan adalah menilai $Q$-Square untuk model structural. Uji Q-Square predictive relevance bertujuan untukmengukur seberapa baik nilai observasi yang dihasilkan oleh model dan juga estimasi parameternya. Nilai Q-Square yang menunjukkan > 0 dapat diartikan sebagai model yang mempunyai predictive relevance sebaliknya jika nilai Q-Square yang nilainya $<0$ maka dapat diartikan nilai tersebut tidak predictive relevance. Berikut dibawah ini perhitungan $\mathrm{Q}-$ Square yang dilakukan dengan rumus :

$$
\mathrm{Q}^{2}=1-\left(1-\mathrm{R}_{1}^{2}\right)\left(1-\mathrm{R}_{2}^{2}\right) \ldots\left(1-\mathrm{R}_{\mathrm{p}}^{2}\right)
$$

$$
\begin{array}{llllll}
\mathrm{R}_{1}{ }^{2}, & \mathrm{R}_{2}{ }^{2} & \ldots & \mathrm{R}_{\mathrm{p}}{ }^{2} & \text { menunjukan }
\end{array}
$$

Square variabel endogen dalam model persamaan. Besaran $\mathrm{Q}^{2}$ memiliki rentang $0<\mathrm{Q}^{2}<1$, dimana semakin mendekati 1 maka struktur model tersebut semakin bagus.

$$
\begin{aligned}
Q^{2} & =1-\left(1-R_{1}^{2}\right) \\
& =1-(1-0,902) \\
& =1-0,098 \\
& =0,902
\end{aligned}
$$

Terlihat bahwa hasil $Q^{2}$ diatas adalah sebesar 0,902. Hasil tersebut sesuai dengan ketentuan, bahwa besaran $Q^{2}$ memiliki rentang $0<\mathrm{Q}^{2}<1$, dimana semakin mendekati angka 1 maka model tersebut akan semakin baik. Jadi $0<$ 
$0,902<1$, maka struktur modal penelitian semakin baik sesuai dengan ketentuan dan dapat diprediksi.

\section{G. Uji Hipotesis}

Ujiselanjutnya yaitu uji hipotesis dengan melihat signifikansi pengaruh literasi keuangan, inklusi keuangan dan pendapatan terhadap perilaku keuangan dengan melihat nilai koefisien parameter dan nilai signifikansi t-statistik yang dilihat dari algorithm boostsrapping pada Smart PLS 3.0. Maka sesuai dengan hasil pengolahan data untuk model struktural bagian koefisien analisis jalur (path coefficient), mendapatkan hasil sebagai berikut:

\section{Tabel 10}

Hasil Nilai Koefisien Analisis Jalur

\begin{tabular}{lccccc}
\hline & $\begin{array}{c}\text { Original } \\
\text { Sample } \\
(\mathrm{O})\end{array}$ & $\begin{array}{c}\text { Sample } \\
\text { Mean } \\
(\mathrm{M})\end{array}$ & $\begin{array}{c}\text { Standard } \\
\text { Deviation } \\
(\text { STDEV })\end{array}$ & $\begin{array}{c}\text { T Statistic } \\
(\mid \mathrm{O} / \mathrm{STDE} \\
\mathrm{V} \mid)\end{array}$ & $\begin{array}{c}\mathrm{P} \\
\text { Values }\end{array}$ \\
\hline $\begin{array}{l}\text { Literasi Keuangan - } \\
\begin{array}{l}\text { Perilaku Keuangan } \\
\text { Pnklusi Keuangan - }\end{array}\end{array}$ & 0,264 & 0,269 & 0,083 & 3,117 & 0,002 \\
$\begin{array}{l}>\text { Perilaku } \\
\text { Keuangan }\end{array}$ & 0,600 & 0,587 & 0,069 & 8,653 & 0,000 \\
\hline $\begin{array}{l}\text { Pendapatan -> } \\
\text { Perilaku Keuangan }\end{array}$ & 0,131 & 0,130 & 0,058 & 2,265 & 0,024 \\
\hline
\end{tabular}

Sumber: Hasil Output SmartPLS 3.0.

Berdasarkan tabel diatas terlihat pada kolom Original Sample $(\mathrm{O})$ bahwa hasil nilai koefisien analisis jalur, dapat disimpulkan pengujian antar variabel literasi keuangan terhadap perilaku keuangan sebesar 0,264, inklusi keuangan terhadap perilaku keuangan sebesar 0,600 dan pendapatan terhadapperilaku keuangan sebesar 0,131 . Hasil tersebut dapat menunjukan adanya pengaruh literasi keuangan, inklusi keuangan dan pendapatan terhadap perilaku keuangan.

\section{Uji t-Statistik}

Uji t atau uji parsial digunakan untuk mengetahui ada atau tidaknya pengaruh signifikan antara literasi keuangan $\left(\mathrm{X}_{1}\right)$, inklusi keuangan $\left(\mathrm{X}_{2}\right)$, pendapatan $\left(\mathrm{X}_{3}\right)$ terhadap perilaku keuangan $(\mathrm{Y})$. Diketahui t tabel $=1,661$ yang diperoleh dari rumus $\mathrm{df}=\mathrm{n}-\mathrm{k}$ atau $\mathrm{df}=100-4=96$, kemudian dihubungkan dengan derajat kepercayaan 5\% atau 0,05. Berdasarkan hasil pengolahan data untuk uji signifikansi (Uji t) diperoleh hasil sebagai berikut: 
Tabel 11

Hasil Nilai t - Statistik

\begin{tabular}{lcc}
\hline & $\begin{array}{c}\text { T Statistic } \\
(\mid \text { O/STDEV } \mid)\end{array}$ & P Values \\
\hline Literasi Keuangan -> Perilaku Keuangan & 3,117 & 0,002 \\
\hline Inklusi Keuangan -> Perilaku Keuangan & 8,653 & 0,000 \\
\hline Pendapatan-> Perilaku Keuangan & 2,265 & 0,024 \\
\hline
\end{tabular}

Sumber: Hasil Output SmartPLS 3.0.

Maka dengan hasil uji t-Statistik dapat disimpulkan :

a.Hasil pengujian variabel literasi keuangan terhadap perilaku keuangan menunjukan nilai $t_{\text {hitung }} 3,117>t_{\text {tabel }}$ 1,661 dan nilai Signifikan sebesar 0,002 < 0,05 ini menunjukan bahwa literasi keuangan berpengaruh terhadap perilaku keuangan.

b.Hasil pengujian variabel inklusi keuangan terhadap perilaku keuangan menunjukan nilai thitung $8,653>t_{\text {tabel }} 1,661$ dan nilai Signifikan sebesar $0,000<$ 0,05 ini menunjukan bahwa inklusi keuangan berpengaruh terhadap perilaku keuangan.

c.Hasil pengujian variabel pendapatan terhadap perilaku keuangan menunjukan nilai $t_{\text {hitung }} 2,265>t_{\text {tabel }} 1,661$ dan nilai Signifikan sebesar 0,024 $<0,05$ ini menunjukan bahwa pendapatan berpengaruh terhadap perilaku keuangan.

Dibawah ini merupakan gambaran rangkuman hasil perhitungan dan pengujian koefisien jalur : 


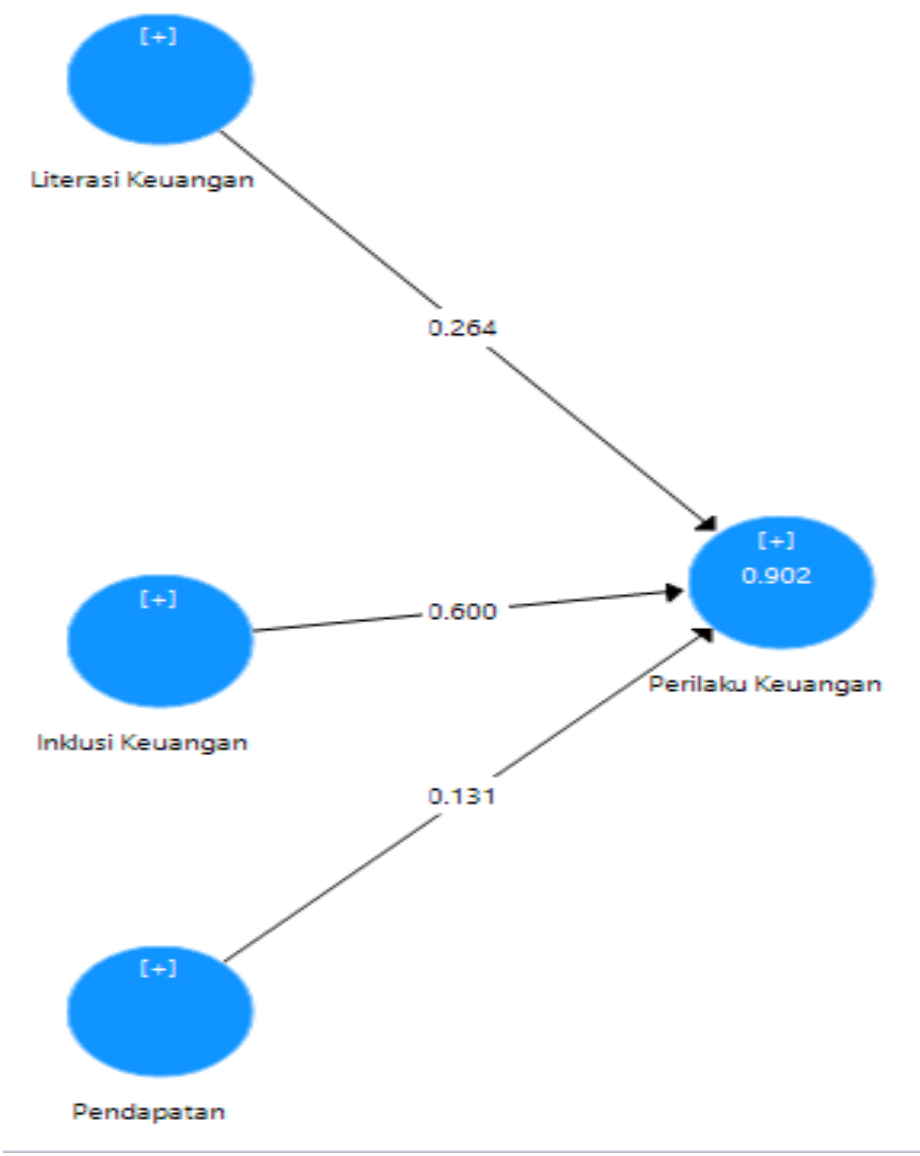

Sumber: Hasil Ouput SmartPLS 3.0.

\section{Gambar 3}

\section{Inner Model}

Interpretasi Hasil Koefisien Jalur :

a. Koefisien jalur variabel $\mathrm{X}_{1}$ terhadap $\mathrm{Y}$ sebesar 0,264

b. Koefisien jalur variabel $\mathrm{X}_{2}$ terhadap $\mathrm{Y}$ sebesar 0,600

c. Koefisien jalur variabel $\mathrm{X}_{3}$ terhadap $\mathrm{Y}$ sebesar 0,131

\section{H. Pengaruh Literasi Keuangan terhadap Perilaku Keuangan}

Berdasarkan hasil penelitian pengujian hipotesis menunjukan literasi keuangan berpengaruh positif terhadap perilaku keuangan. Hal tersebut ditunjukan dengan nilai $\mathrm{t}_{\text {hitung }} 3,117>\mathrm{t}_{\text {tabel }}$ 1,661 dan nilai signifikansi sebesar $0,002<0,05$ lalu nilai original sample sebesar 0,264 yang berarti terdapat pengaruh literasi keuangan terhadap perilaku keuangan pada pelaku Usaha Mikro, Kecil dan Menengah Kota Depok. Berarti indikator-indikator literasi keuangan seperti pengetahuan pengelolaan keuangan, pengetahuan perencanaan keuangan, pengetahuan kredit dan pengetahuan investasi dapat mempengaruhi Perilaku Keuangan UMKM Kota Depok. Literasi keuangan para pelaku UMKM di Kota Depok masih rendah diakibatkan oleh tingkat pendidikan formal yang dimiliki lebih banyak pada SD sampai SMA yaitu sebesar $96 \%$ sedangkan $6 \%$ berasal dari S1/S2/S3 dan pendidikan lainnya. Selain itu, masih kurangnya sosialisasi yang diberikan oleh dinas UMKM 
kepada para pelaku UMKM mengenai pengelolaan keuangan dan pembuatan laporan keuangan yang baik. pengetahuan yang minim mempengaruhi perilaku keuangan para pelaku UMKM Kota Depok sehingga banyak pelaku UMKM yang tidak mencatat perencanaan dalam keuangan, tidak memisahkan keuangan pribadi dan usaha serta tidak menggunakan kredit untuk mengembangkan usaha.

Penelitian ini sejalan dengan (Fatimah, n.d.; Hamdani \& Mawardi, 2018; Herawati, 2015; Sari, 2015) yang dalam penelitiannya menyimpulkan bahwa variabel literasi keuangan berpengaruh positif terhadap perilaku keuangan. Maka hasil penelitian ini sesuai dengan hipotesis yang telah dibuat yaitu terdapat pengaruh literasi keuangan terhadap perilaku keuangan UMKM di Kota Depok yang artinya $\mathrm{H}_{1}$ diterima dan $\mathrm{H}_{0}$ ditolak.

\section{Pengaruh Inklusi Keuangan terhadap Perilaku Keuangan}

Berdasarkan hasil penelitian pengujian hipotesis menunjukan inklusi keuangan berpengaruh positif terhadap perilaku keuangan. Hal tersebut ditunjukan dengan nilai $\mathrm{t}_{\text {hitung }} 8,653>\mathrm{t}_{\text {tabel }} 1,661$ dan nilai signifikansi sebesar $0,000<0,05$ lalu nilai original sample sebesar 0,600 yang berarti terdapat pengaruh inklusi keuangan terhadap perilaku keuangan pada pelaku Usaha Mikro, Kecil dan Menengah (UMKM) di Kota Depok. Dapat diartikan pula bahwa dalam indikator-indikator inklusi keuangan seperti pengetahuan ragam produk dan jasa keuangan, risiko produk keuangan, perlindungan nasabah dan keterampilan mengelola keuangan dapat mempengaruhi perilaku keuangan UMKM di Kota Depok. Para pelaku UMKM di Kota Depok memiliki inklusi keuangan yang rendah karena minimnya pengetahuan mengenai layanan jasa keuangan, perlindungan nasabah, pendapatan rata-rata yang masih kecil dan banyak yang tidak membuat anggaran pengeluaran.

\section{J. Pengaruh pendapatan terhadap Perilaku Keuangan}

Berdasarkan hasil penelitian pengujian hipotesis menunjukan pendapatan berpengaruh positif terhadap perilaku keuangan. Hal tersebut ditunjukan dengan nilai $\mathrm{t}_{\text {hitung }} 2,265>\mathrm{t}_{\text {tabel }} 1,661$ dan nilai signifikansi sebesar $0,024<0,05$ lalu nilai original sample sebesar 0,131 yang berarti terdapat pengaruh pendapatan terhadap perilaku keuangan pada pelaku Usaha Mikro, Kecil dan Menengah (UMKM) di Kota Depok. Dapat diartikan pula bahwa dalam indikator-indikator pendapatan yaitu pendapatan langsung dan pendapatan tidak langsung dapat mempengaruhi perilaku keuangan pelaku UMKM di Kota Depok. Sesuai dengan pembahasan di atas bahwa pelaku UMKM di Kota Depok banyak yang tidak meminjam uang ke bank karena tidak membuatnya laporan keuangan, banyak pelaku UMKM yang menabung di individu tidak pada lembaga bank dan pendapatan yang minim membuat para pelaku UMKM tidak memiliki tabungan sehingga mengalokasikan pendapatan untuk kebutuhan sehari-hari.

Penelitian ini sejalan dengan penelitian yang dilakukan oleh (Wahyudi, Tukan, \& Pinem, 2020) yang mengatakan bahwa pendapatan berpengaruh positif terhadap 
perilaku keuangan. Maka hasil penelitian ini sesuai dengan hipotesis yang telah dibuat yaitu terdapat pengaruh pendapatan terhadap perilaku keuangan pelaku UMKM di Kota Depok yang artinya $\mathrm{H}_{3}$ diterima dan $\mathrm{H}_{0}$ ditolak. Artinya Jika pelaku UMKM mempunyai pengetahuan tentang Literasi Keuangan dapat memberikan efek yang positif kepada pelaku UMKM khususnya kesejahtraannya lebih baik.

\section{Kesimpulan}

Hasil penelitian menunjukkan bahwa semakin tinggi tingkat literasi keuangan , akses terhadap Lembaga Keuangan maka semakin tinggi pula perkembangan kinerja UMKM di wilayah Depok. Sehingga, tingkat literasi keuangan sangat penting bagi perkembangan suatu usaha, karena sebuah bisnis yang baik perlu didukung dengan pengelolaan keuangan yang baik pula. Hasil yang diperoleh menunjukkan hal yang positif jika pemahaman UMKM tentang Literasi Keuangan semakin baik akan semakin mampu dalam membuat Keputusan yang tepat dan efektif, sehingga terhindar dari kesalahan dalam mengelola keuangan. khususnya tingkat akses terhadap lembaga Keuangan merupakan salah satu hal penting yang harus menjadi fokus pelaku UMKM dalam mengelola bisnis karena akan berdampak pada Kinerja dan Keberlanjutan usaha mereka. 


\section{BIBLIOGRAFI}

Al Kholilah, Naila, \& Iramani, Rr. (2013). Studi Financial Management Behavior Pada Masyarakat Surabaya. Journal of Business and Banking, 3(1), 69-80.

Bodie, Zvi, Kane, Alex, \& Marcus, Alan J. (2014). Manajemen Portofolio dan Investasi. Jakarta (ID): Salemba Empat.

Bongomin, George Okello Candiya, Ntayi, Joseph Mpeera, Munene, John C., \& Malinga, Charles Akol. (2017). The relationship between access to finance and growth of SMEs in developing economies. Review of International Business and Strategy.

Fatimah, Nur. (n.d.). Susanti.(2018). Pengaruh Pembelajaran Akuntansi Keuangan, Literasi Keuangan, dan Pendapatan Terhadap Perilaku Keuangan Mahasiswa Fakultas Ekonomi Universitas Muhammadiyah Gresik. Jurnal Pendidikan Akuntansi (JPAK), 6(1), 48-57.

Ferdinan, A. (2014). Metode Penelitian Manajemen. Edisi Lima. Semarang: Undip Press.

Ghozali, Imam. (2016). Aplikasi Analisis Multivariete Dengan Program IBM SPSS 23 Edisi 8 (8th ed.). Semarang: Universitas Diponogoro.

Hamdani, Muhammad Yusuf, \& Mawardi, M. Kholid. (2018). Pengaruh Viral Marketing Terhadap Kepercayaan Konsumen Serta Dampaknya Terhadap Keputusan Pembelian (Survei pada Mahasiswa Fakultas Ilmu Administrasi Universitas Brawiijaya Angkatan 2015/2016 yang pernah Melakukan Pembelian Online melalui Media Sosial In. Jurnal Administrasi Bisnis, 60(1), 163-171.

Herawati, Nyoman Trisna. (2015). Kontribusi pembelajaran di perguruan tinggi dan literasi keuangan terhadap perilaku keuangan mahasiswa. Jurnal Pendidikan Dan Pengajaran, 48(1-3).

Hidayat, Yusup, Fuad, Fokky, \& Nurhidayati, Maslihati. (2018). Implementation of economic democracy principle in Islamic banking policies through Financial Services Authority (FSA) in Indonesia. At-Taradhi: J Stu Eko, 8(2), 132-154.

Keuangan, Otoritas Jasa. (2015). Otoritas Jasa Keuangan. Dipetik April, 14, 2017.

Purwidianti, Wida, \& Mudjiyanti, Rina. (2016). Analisis Pengaruh Pengalaman Keuangan Dan Tingkat Pendapatan Terhadap Perilaku Keuangan Keluarga Di Kecamatan Purwokerto Timur. Benefit: Jurnal Manajemen Dan Bisnis, 1(2), 141148.

Sari, Dian Anita. (2015). Finalcial Literacy Dan Perilaku Keuangan Mahasiswa (Studi Kasus Mahasiswa Stie 'Yppi'Rembang). BBM (Buletin Bisnis \& Manajemen), 1(2).

Sugiyono. (2016). Metode Penelitian Kuantitatif, Kualitatif, dan R\&D. Bandung: Alfabeta. 
Dahlia Pinem dan Bernadin Dwi M

Suryanto, Tulus. (2017). Manajemen Laba Pada Bank Syariah Di Indonesia: Peran Komite Audit Dan Dewan Pengawas Syariah. KINERJA, Volume 18, No.1, Th. 2014: Hal. 90-100

Wahyudi, Wahyudi, Tukan, Brigitta Azalea Pulo, \& Pinem, Dahlia. (2020). Analysis of The Effect of Financial Literation, Financial Technology, Income, and Locus of Control on Lecturer Financial Behavior. AFEBI Management and Business Review, 5(01), 37-46.

Wirjono, Endang Raino, \& Raharjono, Agus Budi. (2012). Survei Pemahaman dan Pemanfaatan Informasi Akuntansi dalam Usaha Kecil Menengah di Daerah Istimewa Yogyakarta. AUDI Jurnal Akuntansi Dan Bisnis, 7(2). 